\author{
A. Serkov ${ }^{1}$, V. Breslavets ${ }^{1}$, I. Yakovenko ${ }^{1}$, O. Dziabenko ${ }^{2}$ \\ ${ }^{1}$ National Technical University "Kharkiv Polytechnic Institute", Kharkiv, Ukraine \\ ${ }^{2}$ University of Deusto, Bilbao, Spain
}

\title{
EXCITATION OF SURFACE VIBRATIONS OF SEMICONDUCTOR STRUCTURES EXPOSED TO EXTERNAL ELECTROMAGNETIC RADIATION
}

\begin{abstract}
The subject of the study are processes of manifestation of instabilities of natural oscillations of semiconductor structures, which are caused by the mechanisms of interaction of charged particle flows in the presence of powerful external electromagnetic radiation. The goal is to obtain design relationships that allow determining the degree of deviation of the performance characteristics of semiconductor components from the norm, depending on the parameters of the external pulsed electromagnetic field. The task is to construct a model of interaction induced by external electromagnetic radiation currents with electrostatic oscillations of the semiconductor structure. The model is based on the realization of the resonance (Cherenkov) interaction of moving charges and electromagnetic oscillations under conditions where the phase velocity of the wave and the velocity of the charged particle are the same. The methods used: analytical methods for solving the Maxwell equations and the equations of the medium in the framework of the hydrodynamic approach. The following results are obtained. Investigations of the functioning of semiconductor components of electronic equipment under the influence of strong-pulsed electromagnetic fields are carried out. The nature of changes in the working capacity of semiconductor components of the hardware component base is determined. It is shown that the influence of pulsed electromagnetic radiation is accompanied by the appearance of currents in the conductive elements of products and the appearance of intrinsic internal fields. One of the types of reversible failures of the semiconductor element base of electronic products is determined, based on the interaction of currents induced by external radiation with the intrinsic fields of the structures that complete the product. Similar failures are realized under conditions of Cherenkov radiation, when the current is parallel to the boundary of the structure. It is shown that this interaction leads to energy losses of the induced currents to excitation of the natural vibrations of the structure, i.e. the appearance of a mode of oscillation generation, which is characterized by a change in the volt-ampere characteristics of radio products. Conclusions. The comparative analysis of quantitative evaluations of reversible failures of semiconductor devices depending on the spatial configuration of the acting field, in which the induced current is paralleled to the structure boundary, allows solving problems of optimizing the degree of distortion of the performance characteristics of these devices. The results obtained in the work can be used to evaluate the efficiency of active radioelectronic devices, for example, amplifiers, generators and converters of electromagnetic oscillations in the millimeter and submillimeter ranges under the influence of powerful external pulsed electromagnetic fields.
\end{abstract}

Keywords: electromagnetic radiation; Semiconductor structures; Surface oscillations; Charged particles; Vibration decrement.

\section{Introduction}

Most of the available theoretical and experimental results of studies of the influence of EMR on radio devices are related to the field of irreversible failures. Modeling of the mechanisms of interaction of induced currents and voltages with the processes characterizing the functional purpose of products is usually carried out within the framework of the theory of chains with distributed parameters. This approach makes it possible to evaluate the performance criteria as a whole (for example, to estimate the critical energy characterizing a thermal breakdown), but the issues related to determination of various kinds of electromagnetic interactions that occur directly in component parts exposed to EMR remain unsolved.

Expansion of application areas and increase in the processing speed of radio electronic equipment (REE) lead to a need for increasing use of element base containing semiconductor electronics products [1]. This increases the degree of influence that external electromagnetic radiation (EMR) produces on the performance of REE, taking into account that semiconductor components have an increased sensitivity to EMR.

All kinds of failures that arise in REE resulting from the influence of external factors are usually classified as reversible and irreversible [2]. Irreversible failures are characterized by a complete loss of functional characteristics of REE. Such failures occur when a change in the internal parameters of the equipment exceeds the permissible limits (with external EMR, irreversible failures usually occur due to a thermal breakdown of the components). For reversible failures, a temporary loss of performance is typical, leading to a distortion of the output characteristics.

This paper to some extent compensates the existing gap in this area of research on reversible failures. We study the interaction of charged particle fluxes induced by EMR with wave processes in semiconductor structures used in modern microwave electronics.

\section{Task solution}

The object of the study is surface oscillations of the semiconductor structures used in radio hardware components and the mechanisms of their interaction with the conduction electrons, leading to damping of the oscillations being exposed to an external electromagnetic field. Let us consider the attenuation of surface plasmons on the boundary of two media, which at $\mathrm{T}=0$ are characterized by dielectric permeability

$$
\varepsilon_{i}=\varepsilon_{0 i}-\omega_{0 i}^{2} / \omega^{2}
$$


To find the spectrum and collisionless damping of surface oscillations under conditions of neglecting the delay effect of the electromagnetic field, we use the following equations:

$$
\begin{aligned}
& \operatorname{rot} \vec{E}(x, y, t)=0 \text {; } \\
& \vec{E}(x, y, t)=\vec{E}\left(\omega, q_{x}, y\right) e^{i\left(q_{x} x-\omega t\right)} \text {; } \\
& \vec{E}\left(\omega, q_{x}, y\right)=\left(E_{x}, E_{y}, 0\right) ; \\
& \operatorname{div} \vec{D}(\omega, x, y)=0 \\
& \vec{D}(\omega, x, y)=\varepsilon_{0}(y) \vec{E}(\omega, x, y)+\frac{4 \pi i}{\omega} \vec{j}(\omega, x, y) \\
& \varepsilon_{0}(y)=\left\{\begin{array}{ll}
\varepsilon_{01}, & y>0 ; \\
\varepsilon_{02}, & y<0 ;
\end{array} \quad \vec{E}= \begin{cases}\vec{E}_{1}, & y>0 \\
\vec{E}_{2}, & y<0\end{cases} \right. \\
& \vec{j}= \begin{cases}\vec{j}_{1}, & y>0 \\
\vec{j}_{2}, & y<0\end{cases}
\end{aligned}
$$

with the following boundary conditions at $y=0$ : the continuity of the tangential components of the electric field is $E_{x}$ and the normal components of the electric induction are $\mathrm{D}_{\mathrm{y}}$.

We start from a model of a homogeneous medium. In other words, we assume that, as in the case of cold plasma, both media are infinite, and the fields and currents in each of them satisfy the boundary conditions on the plane $y=0$ and decrease when $y \rightarrow \pm \infty$. Obviously, such a model is completely justified if the boundary is transparent for particles; i.e. the height of the potential barrier is small in comparison to the energy of the particles. Wherein $\omega_{01}=\omega_{02} ; \varepsilon_{01} \neq \varepsilon_{02}$.

On the other hand, if the media are separated by an infinitely high potential barrier $\omega_{01} \neq \omega_{02}$, then the particles experience an elastic (mirror) reflection from both sides of the barrier, and the electromagnetic properties of such a semi-bounded medium are known to be identical to an unlimited medium. In this case, the results obtained in [3] for a classical approximation for a plasma-dielectric boundary (a nonabsorbent medium) can be transferred to the case of two plasma-like media separated by a dielectric layer whose thickness is small in comparison with the wavelength.

Then the material equation can be written:

$$
\vec{j}(\omega, \vec{r})=-\frac{e^{2} n_{0}}{m c} \vec{A}(\omega, r)+\vec{j}^{\prime}(\omega, r) .
$$

Here $\vec{A}(\omega, \vec{r})=\frac{c}{i \omega} \vec{E}(\omega, \vec{r})$ is a vector potential, $n_{0}=\sum \rho_{k}^{0} \psi_{k}^{*}(\vec{r}) \psi_{k}(\vec{r})$ is the equilibrium concentration of charge carriers, $\rho_{k}^{0}$ is their equilibrium distribution function, $\psi_{k}(\vec{r})=V^{-1 / 2} \exp (i k \vec{r})$ is the wave function of a particle with the dispersion law $E_{k}=\frac{\hbar^{2} k^{2}}{2 m}, \quad V$ is the volume of the medium, $\vec{j}^{\prime}(\omega, \vec{r})=\sum \rho_{k k^{\prime}}(\omega) \vec{j}_{k^{\prime} k}(\vec{r})$ is the conductivity current due to electron transitions between states $k$ and $k^{\prime}\left(k_{z}=k_{z}^{\prime}\right)$ due to inelastic scattering with a potential $\vec{A}(\omega, \vec{r})=\vec{A}\left(\omega, q_{x}, y\right) \mathrm{e}^{i\left(q_{x} x-\omega t\right)}$ (we further assume for definiteness that $\left.q_{x}>0, \omega>0\right)$, and $\rho_{k k^{\prime}}^{0}(\omega)$ is the perturbed off-diagonal correction to the equilibrium particle distribution function, determined from the equation of motion for the density matrix [2]:

$$
\begin{gathered}
\rho_{k k^{\prime}}(\omega)=\frac{\rho_{k}^{0}-\rho_{k^{\prime}}^{0}}{\hbar\left(\omega_{k k^{\prime}}-\omega^{*}\right)} H_{k k^{\prime}}(\omega) ; \\
\omega_{k k^{\prime}}=\frac{\hbar\left(k^{2}-k^{\prime 2}\right)}{2 m} ; \omega^{*}=\omega+i v, v \rightarrow 0 ; \\
H_{k k^{\prime}}=\frac{i e \hbar}{2 m c} \int \psi_{k}^{*}(\vec{r})(\vec{A} \nabla+\nabla \vec{A}) \psi_{k^{\prime}}(\vec{r}) d \vec{r}
\end{gathered}
$$

is the matrix element of the Hamiltonian of interaction of charge carriers with an electromagnetic field.

$$
\vec{j}_{k k^{\prime}}=\frac{i e \hbar}{2 m}\left\{\nabla \psi_{k^{\prime}}^{*}(r) \psi_{k}(\vec{r})-\psi_{k^{\prime}}^{*}(r) \nabla \psi_{k}(\vec{r})\right\}
$$

is the matrix element of the particle current density operator. You can finally convert $\vec{j}^{\prime}(\omega, \vec{r})$ to the following form:

$$
\begin{gathered}
\vec{j}^{\prime}(\omega, \vec{r})=-\frac{1}{\hbar c} \sum \vec{j}_{k^{\prime} k}(\vec{r}) \frac{\left(\rho_{k}^{0}-\rho_{k^{\prime}}^{0}\right)}{\omega_{k k^{\prime}}-\omega^{*}} \times \\
\times\left[H_{k k^{\prime}}^{S}(\omega)+\int \vec{j}_{k k^{\prime}}(\vec{r}) \vec{A}(\omega, \vec{r}) d \vec{r}\right],
\end{gathered}
$$

where

$$
H_{k k^{\prime}}^{S}=\frac{i e \hbar}{2 m c} \int_{\times\left[A_{y}(\omega, x,+0)-A_{y}(\omega, x,-0)\right]}^{d x d z \psi_{k}^{*}(x, 0, z) \psi_{k^{\prime}}(x, o, z) \times}
$$

Thus, in equation (3) for the total current, the first term determines the frequency of the surface plasmons; the second term must determine their damping.

Substituting further $\vec{j}(\omega, \vec{r})$ into equation (2) and taking into account equation (3), we obtain:

$$
\begin{gathered}
\frac{\partial^{2} A_{x}(\omega, x, y)}{\partial y^{2}}-q_{x}^{2} A_{x}(\omega, x, y)= \\
=-\frac{4 \pi i q_{x} c}{\omega^{2} \varepsilon(\omega)} \operatorname{div} \vec{j}^{\prime}(\omega, x, y) ; \\
\varepsilon(\omega)= \begin{cases}\varepsilon_{1}(\omega), & y>0 \\
\varepsilon_{2}(\omega), & y<0\end{cases}
\end{gathered}
$$

Since the damping decrement is small in comparison with the oscillation frequency, the solution of (7) is sought using the method of successive approximations. Assuming that the right-hand side in the first approximation is equal to zero, we find the following expressions for the potential in each of the media for $\varepsilon(\omega) \neq 0$ : 


$$
\begin{aligned}
& y>0, \quad A_{1 x}(y)=A_{1} \mathrm{e}^{-q_{x} y}, \quad A_{1 y}=i A_{1 x}(y) \\
& y<0, \quad A_{2 x}(y)=A_{2} \mathrm{e}^{-q_{x} y}, \quad A_{2 y}=-i A_{2 x}(y)
\end{aligned}
$$

Let us extend the potentials to the half-spaces of $y<0$ and $y>0$ respectively:

$$
A_{x}(-y)=A_{x}(y) ; \quad A_{y}(-y)=-A_{y}(y) .
$$

Thus, the normal component $\vec{A}(y)$ undergoes a discontinuity in the plane of $y=0$. Substituting the values of $\vec{A}(\omega, \vec{r})$ in equation (3) and integrating over the whole space $\vec{r}$, we obtain the following results after replacing the summation $\sum_{k}$ by integration $\frac{V}{(2 \pi)^{3}} \int d \vec{k}$ :

$$
\begin{gathered}
\vec{j}^{\prime}(\omega, \vec{r})= \\
=\frac{e^{2} \hbar A \mathrm{e}^{i q_{x} x}}{2(2 \pi)^{4} m^{2} c} \cdot \int \frac{d \vec{k} d k_{y}^{\prime}}{\omega_{k k^{\prime}}-\omega^{*}}\left(\rho_{k}^{0}-\rho_{k^{\prime}}^{0}\right)\left(\vec{k}+\vec{k}^{\prime}\right) \times \\
\times\left[1-\frac{k^{2}-k^{\prime 2}}{q_{x}^{2}+\left(k_{y}-k_{y}^{\prime}\right)^{2}}\right] \mathrm{e}^{i\left(k_{y}-k_{y}^{\prime}\right) y} .
\end{gathered}
$$

Here $\quad k_{x}^{\prime}=k_{x}-q_{x}, \quad k_{z}^{\prime}=k_{z}$.

The term that is proportional to $\rho_{k}^{0}$ determines the current resulting from the transition of an electron from state $k$ to state $k^{\prime}$ with emission of $\hbar \omega$ quantum of electromagnetic field. Here it is possible to carry out integration $k_{y}^{\prime}$, taking into account the contributions of poles $k_{y}^{\prime 2}=k_{y}^{2}-\frac{2 m(\omega+i v)}{\hbar}$ at $k_{x}>>q_{x}, \omega>q_{x} v_{x}$.

The term with $\rho_{k^{\prime}}^{0}$ determines the current associated with the transitions of electrons from the state $k^{\prime}$ to the state $k$ upon absorption of energy $\hbar \omega$. This current is determined by the poles $k_{y}^{2}=k_{y}^{\prime 2}+\frac{2 m(\omega+i v)}{\hbar}$ when integrating over $k_{y}$. As a result of integration, we get:

$$
\begin{gathered}
\vec{j}^{\prime}(\omega, \vec{r})=\frac{-i e^{2} \omega A \mathrm{e}^{i q_{x} x}}{(2 \pi)^{3} \hbar c} \times \\
\times\left\{\frac{d \vec{k}\left(\vec{k}+\vec{k}_{-}\right) \rho_{k}^{0}}{k_{y}^{-}\left(k_{y}-k_{y}^{-}\right)^{2}}\left[1-\frac{\hbar\left(k_{y}-k_{y}^{-}\right)^{2}}{2 m \omega}\right] \times\right. \\
\times \exp \left\{i\left[k_{y}-k_{y}^{-}+i \delta_{-}\right] y\right\}- \\
-\int \frac{d \vec{k}\left(\vec{k}+\vec{k}_{+}\right) \rho_{k}^{0}}{k_{y}^{+}\left(k_{y}-k_{y}^{+}\right)^{2}}\left[1-\frac{\hbar\left(k_{y}-k_{y}^{-}\right)^{2}}{2 m \omega}\right] \times \\
\left.\times \exp \left\{i\left[k^{+}{ }_{y}-k_{y}+i \delta_{+}\right] y\right\}\right\} .
\end{gathered}
$$

Here: $\quad y<0, k_{y}^{ \pm}=\sqrt{k_{y}^{2} \pm 2 m \omega / \hbar}>0$,

$$
\vec{k}_{ \pm}=\left(k_{x}, k_{y}^{ \pm}, k_{z}\right), \delta_{ \pm}=\frac{m u}{\hbar k_{y}^{ \pm}} .
$$

The symbol $\int^{\prime}$ means that integration over $k_{y}$ is carried out in regions $\left(-\infty,-\sqrt{\frac{2 m \omega}{\hbar}} ; \sqrt{\frac{2 m \omega}{\hbar}}, \infty\right)$ where the process of radiation of a quantum of energy by an electron is possible. A similar expression for $\vec{j}^{\prime}$ can be easily obtained in $y<0$ region.

It can be seen that the current $\vec{j}^{\prime}(\omega, \vec{r})$ resulting from electronic transitions between states $k_{y}$ and $k_{y}^{\prime}$ is an infinite set of spatial harmonics with a period of $2 \pi /\left|k_{y}-k_{y}^{ \pm}\right|$depending on the frequency of the field and the momentum of the particle, with an amplitude decreasing from the boundary as $\exp \left(-\delta_{ \pm}|y|\right.$. In the classical limit of $k_{y}^{2}, k_{y}^{\prime 2}>2 m \omega / \hbar$ such harmonics are known as "Van Kampen waves" whose phase velocity is equal to the velocity of the particle. Substituting (6) into equation (7), we find the potential excited by the current $\vec{j}^{\prime}(\omega, x, y)$

$$
\begin{gathered}
A_{x}^{\prime}\left(\omega, q_{x}, y\right)=\frac{i \alpha\left(\omega, q_{x}, y\right)}{\varepsilon(\omega)} A \\
A_{y}^{\prime}\left(\omega, q_{x}, y\right)=\frac{A}{q_{x} \varepsilon(\omega)} \frac{\partial \alpha}{\partial y}\left(\omega, q_{x}, y\right) \\
\alpha\left(\omega, q_{x}, y\right)=\frac{e^{2} q_{x} m}{\pi^{2} \hbar^{2}} \times \\
\times\left\{\int^{\prime} \frac{\rho_{k}^{0} d \vec{k}}{k_{y}^{-}\left(k_{y} \mp k_{y}^{-}\right)^{4}}\left[1-\frac{\hbar\left(k_{y} \mp k_{y}^{-}\right)^{2}}{2 m \omega}\right] \times\right. \\
\times \exp \left\{i\left(k_{y} \mp k_{y}^{-} \pm i \delta_{-}\right) y\right\}- \\
\int^{\prime} \frac{\rho_{k}^{0} d \vec{k}}{k_{y}^{+}\left(k_{y} \mp k_{y}^{+}\right)^{4}}\left[1-\frac{\hbar\left(k_{y} \mp k_{y}^{+}\right)^{2}}{2 m \omega}\right] \times \\
\times \exp \left\{i\left( \pm k_{y}^{+}-k_{y} \pm i \delta_{+}\right) y\right\} .
\end{gathered}
$$

Here the upper signs in front of $k_{y}^{\mp}$ and $\delta_{\mp}$ refer to $y>0$ half-space, and the lower ones - to $y<0$ halfspace. By means of the boundary conditions, we can now eliminate the undefined constants $\mathrm{A} 1$ and $\mathrm{A} 2$ and obtain the dispersion equation:

$$
\begin{gathered}
\varepsilon_{1}(\omega)\left[1+i \frac{\alpha_{2}\left(\omega, q_{x}, 0\right)}{\varepsilon_{2}(\omega)}\right]+ \\
+\varepsilon_{2}(\omega)\left[1+i \frac{\alpha_{1}\left(\omega, q_{x}, 0\right)}{\varepsilon_{1}(\omega)}\right]=0 .
\end{gathered}
$$

Hence, when $\left|\frac{\alpha\left(\omega, q_{x}, 0\right)}{\varepsilon(\omega)}\right|<<1$ we get: 


$$
\begin{gathered}
\omega_{s}=\left(\frac{\omega_{01}^{2}+\omega_{02}^{2}}{\varepsilon_{01}+\varepsilon_{02}}\right)^{1 / 2} ; \\
\Delta \omega_{s}=\frac{i \omega_{s}}{2} \frac{\left[\alpha_{1}\left(\omega, q_{x}, 0\right)+\alpha_{2}\left(\omega, q_{x}, 0\right)\right]}{\varepsilon_{01}+\varepsilon_{02}} .
\end{gathered}
$$

\section{Analysis}

Now, let us find the damping decrements in various physical situations. In the case of a Maxwellian electron distribution

$$
\rho_{k}^{0}=\frac{(2 \pi \hbar)^{3} n_{0}}{(2 \pi m T)^{3 / 2}} e^{-\frac{\hbar^{2} k^{2}}{2 m T}}
$$

the expression for $\alpha\left(\omega, q_{x}, 0\right)$ can be converted to the following form:

$$
\begin{gathered}
\alpha\left(\omega, q_{x}, 0\right)=\sqrt{\frac{2}{\pi}} \frac{\omega_{0}^{2} q_{x} \mathrm{v}_{T} T}{\hbar \omega^{4}}\left(\mathrm{e}^{-\frac{\hbar \omega}{T}}-1\right) \times \\
\times \int_{-\infty}^{\infty}\left(x^{2}+\frac{\hbar \omega}{T}\right)^{\frac{1}{2}} x^{2} \mathrm{e}^{-x^{2}} d x .
\end{gathered}
$$

Hence, we obtain:

$$
\begin{aligned}
& \alpha=-2 \frac{\omega_{0}^{2} q_{x} \mathrm{v}_{T}}{\omega_{s}^{3}} \sqrt{\frac{T}{2 \hbar \omega_{s}}}, \frac{\hbar \omega_{s}}{T}>>1 ; \\
& \alpha=-2 \sqrt{\frac{2}{\pi}} \frac{\omega_{0}^{2} q_{x} \mathrm{v}_{T}}{\omega_{s}^{3}}, \quad \frac{\hbar \omega_{s}}{T}<1 .
\end{aligned}
$$

In the case of an infinitely small barrier:

$$
\omega_{01}=\omega_{02}, \quad \varepsilon_{01} \neq \varepsilon_{02}, \omega_{s}=\omega_{0} \sqrt{2 /\left(\varepsilon_{01}+\varepsilon_{02}\right)} ;
$$

the decrements of the oscillations are respectively equal to:

$$
\begin{array}{ll}
\Delta \omega_{s}=-i q_{x} \mathrm{v}_{T} \sqrt{T /\left(2 \hbar \omega_{s}\right)} ; & \hbar \omega_{s}>T ; \\
\Delta \omega_{s}=-\sqrt{2 / \pi} \cdot i q_{x} \mathrm{v}_{T} ; & \hbar \omega_{s}<T .
\end{array}
$$

On the boundary of two plasma media, separated by an infinitely high potential barrier, the expressions for the decrement obtain the following form:

$$
\begin{gathered}
\Delta \omega_{s}=-i \frac{q_{x}}{\sqrt{2 \hbar \omega_{s}}} \frac{\sum \omega_{0 i}^{2} \mathrm{v}_{T i} T_{i}^{1 / 2}}{\sum \omega_{0 i}^{2}} ; \\
\Delta \omega_{s}=-\sqrt{\frac{2}{\pi}} i q_{x} \frac{\sum \omega_{0 i}^{2} \mathrm{v}_{T i}}{\sum \omega_{0 i}^{2}} ; \quad i=1,2 \ldots
\end{gathered}
$$

It is seen that at the plasma-insulator boundary

$$
\omega_{02}=0, \omega_{01}=\omega_{0}, \quad \varepsilon_{2}=\varepsilon_{d}
$$

equations (15) coincide with equations (13) and correspond to the well-known expression for the decrement of surface vibrations [4] under mirror reflection of particles from the boundary.

\section{Conclusions}

A model has been proposed for the interaction of conduction electrons in a semiconducting medium with surface oscillations. The model is based on the implementation of the resonance (Cherenkov) interaction between moving charges and electromagnetic oscillations under conditions where the phase velocity of the wave and the velocity of a charged particle are the same.

The ratios have been calculated relating the following parameters of semiconductor structures: the concentration of free carriers, the dielectric constant, the carrier temperature with the magnitude of the vibration decrement in the classical and quantum approximations.

It has been shown that the impact of pulsed electromagnetic radiation on electronic products is often accompanied by emergence of currents in the conductive elements of hardware and formation of their internal fields.

The mechanisms of interaction of charged particles with natural oscillations of the components of the electronic devices leading to attenuation of surface oscillations in semiconductor structures have been determined.

\section{REFERENCES}

1. Averkov, Yu.O. and Yakovenko, V.M. (2009), "Transition radiation of a modulated electron beam crossing a wire screen", Radiophysics and Electronics, Vol. 14, No. 3, pp. 337-343.

2. Averkov, Yu.O. and Yakovenko, V.M. (2009), "Excitation of surface electrostatic waves in semibounded layered superconductors by a nonrelativistic electron beam", ZhTF, Vol. 79, No. 5, pp. 87-94.

3. Averkov, Yu.O., Bass, F.G. and Yakovenko, V.M. (2009), "Excitation of surface excitons in semi-bounded solids by a nonrelativistic electron beam", FTT, Vol. 51, No. 1, pp. 57-64.

4. Kravchenko, V.I., Yakovenko, V.I., Yakovenko, I.V. and Losev, F.V. (2009), "Impact of extraneous factors on semiconductor components of electronic radio-devices", Vestnik_NTU "KhPI", NTU "KhPI", Kharkiv, No. 11, pp. 62-69.

5. Beletsky, N.N., Khankina, S.I., Yakovenko, V.I. and Yakovenko, I.V. (2010), "Interaction between surface plasmons and charged particle flows passing through the interface", ZhTF, Vol. 80, No. 4, pp. 120-125.

6. Khankina, S.I., Yakovenko, V.I. and Yakovenko, I.V. (2011), "Electronic states on an uneven surface of a solid body surface", FNT, Vol. 37, No. 11, pp. 1148-1155.

7. Kravchenko, V.I., Korobko, A.I. and Yakovenko, I.V. (2014), "Influence of external electromagnetic factors on waveguide characteristics of semiconductor components of electronic devices", Vestnik NTU "KhPI", NTU "KhPI", Kharkiv, No. 21, pp. 79-84.

8. Kravchenko, V.I. and Yakovenko, I.V. (2014), "Mechanisms of failure of semiconductor components of electronic products under the influence of external electromagnetic radiation"', Vestnik NTU "KhPI", NTU "KhPI", Kharkiv, No. 21, pp. 84-88. 


\section{Збудження поверхневих коливань напівпровідникових структур під впливом стороннього електромагнітного випромінювання}

\section{О. А. Серков, В. С. Бреславець, І. В. Яковенко, О. Дзябенко}

Предметом вивчення $є$ процеси виникнення нестійкості власних коливань напівпровідникових структур, які обумовлені механізмами взаємодії потоків заряджених частинок за наявності потужного зовнішнього електромагнітного випромінювання. Мета - отримання розрахункових співвідношень, які дозволяють визначити ступінь відхилення робочих характеристик напівпровідникових комплектуючих від норми в залежності від параметрів зовнішнього імпульсного електромагнітного поля. Задача - побудова моделі взаємодії наведених зовнішніми електромагнітними випромінюваннями струмів 3 електростатичними коливаннями напівпровідникової структури. В основу моделі покладено реалізацію резонансної (черенковської) взаємодії рухливих зарядів та електромагнітних коливань в умовах, коли співпадають фазова швидкість хвилі та швидкість зарядженої частинки. Використані методи: аналітичні методи рішення рівнянь Максвелла та рівнянь середовища в рамках гідродинамічного підходу. Отримані наступні результати. Проведені дослідження функціонування напівпровідникових комплектуючих електрорадіовиробів в умовах дії потужних імпульсних електромагнітних полів. Визначено характер змін працездатності напівпровідникових комплектуючих елементної бази технічних засобів. Показано, що вплив імпульсного електромагнітного випромінювання супроводжується виникненням струмів у провідних елементах виробів та виникненням власних внутрішніх полів. Визначено один з типів зворотніх відмов напівпровідникової елементної бази електрорадіовиробів, що базується на взаємодії струмів, наведених зовнішнім випромінюванням, з власними полями структур комплектуючих виріб. Подібні відмови реалізуються в умовах черенковського випромінювання, коли струм паралельний до кордонів структури. Показано, що дана взаємодія призводить до енергетичних втрат наведеного струму на збудження власних коливань структури, тобто появу режиму генерації коливань, які характеризується зміною вольт-амперних характеристик радіовиробів. Висновки. Проведений порівняльний аналіз кількісних оцінок зворотних відмов у напівпровідникових приладах в залежності від просторової конфігурації впливаючого поля, за яким наведений струм виникає паралельно до кордонів структури, дозволяє вирішувати задачі оптимізації ступеня спотворення робочих характеристик даних приладів. Результати, які отримані в роботі, можуть бути використані під час оцінки працездатності активних радіоелектронних приладів, наприклад, підсилювачів, генераторів та перетворювачів електромагнітних коливань міліметрового та субміліметрового діапазонів в умовах впливу потужних зовнішніх імпульсних електромагнітних полів.

Ключові слова: електромагнітне випромінювання; напівпровідникові структури; поверхневі вібрації; заряджені частинки; декремент коливань.

\section{Возбуждение поверхностных колебаний полупроводниковых структур при воздействии стороннего электромагнитного излучения}

\section{А. А. Серков, В. С. Бреславец, И. В. Яковенко, О. Дзябенко}

Предметом изучения являются процессы проявления неустойчивостей собственных колебаний полупроводниковых структур, которые обусловлены механизмами взаимодействия потоков заряженных частиц при наличии мощного внешнего электромагнитного излучения. Цель - получение расчетных соотношений, позволяющих определять степень отклонения рабочих характеристик полупроводниковых комплектующих от нормы в зависимости от параметров внешнего импульсного электромагнитного поля. Задача - построение модели взаимодействия наведенных внешним электромагнитным излучением токов с электростатическими колебаниями полупроводниковой структуры. В основу модели положена реализация резонансного (черенковского) взаимодействия движущихся зарядов и электромагнитных колебаний в условиях, когда совпадают фазовая скорость волны и скорость заряженной частицы. Используемые методы: аналитические методы решения уравнений Максвелла и уравнений среды в рамках гидродинамического подхода. Получены следующие результаты. Проведены исследования функционирования полупроводниковых комплектующих электрорадиоизделий в условиях воздействия сильных импульсных электромагнитных полей. Определен характер изменений работоспособности полупроводниковых комплектующих элементной базы технических средств. Показано, что влияние импульсного электромагнитного излучения сопровождается возникновением токов в проводящих элементах изделий и возникновением собственных внутренних полей. Определен один из типов обратимых отказов полупроводниковой элементной базы электрорадиоизделий, основанный на взаимодействии токов, наведенных внешним излучением, с собственными полями структур, комплектующих изделие. Подобные отказы реализуются в условиях черенковского излучения, когда ток параллелен границе структуры. Показано, что данное взаимодействие приводит к энергетическим потерям наведенных токов на возбуждение собственных колебаний структуры, т.е. появлению режима генерации колебаний, который характеризуется изменением вольт-амперных характеристик радиоизделий. Выводы. Проведенный сравнительный анализ количественных оценок обратимых отказов полупроводниковых приборов в зависимости от пространственной конфигурации воздействующего поля, при котором наведенный ток паралеллен границе структуры, позволяет решать задачи оптимизации степени искажения рабочих характеристик данных приборов. Результаты, полученные в работе, могут быть использованы при оценке работоспособности активных радиоэлектронных приборов, например, усилителей, генераторов и преобразователей электромагнитных колебаний миллиметрового и субмиллиметрового диапазонов в условиях воздействия мощных внешних импульсных электромагнитных полей.

Ключевые слова: электромагнитное излучение; полупроводниковые структуры; поверхностные колебания; заряженные частицы; декремент колебаний. 